\title{
RESPOSTA DE EIXOS EMBRIONÁRIOS DE CUPUAÇU (Theobroma grandiflorum Schum.) À CONCENTRAÇÃO DE SAIS, DOSES DE SACAROSE E RENOVAÇÃO DO MEIO DE CULTIVO ${ }^{1}$
}

\author{
MARIA DAS GRAÇAS RODRIGUES FERREIRA², FERNANDO ENRIQUE NINAMANGO CÁRDENAS ${ }^{3}$, \\ CARLOS HENRIQUE SIQUEIRA DE CARVALHO ${ }^{4}$, ANDRÉA ALMEIDA CARNEIRO ${ }^{5}$ e \\ CARLOS FERREIRA DAMIÃO FILHO 6
}

\begin{abstract}
RESUMO - Foram estudados os efeitos da concentração de sais, doses de sacarose e freqüência de renovação do meio de cultura para o desenvolvimento de eixos embrionários de cupuaçu (Theobroma grandiflorum Schum.). Testaram-se 2 concentrações de sais MS (100 e 50\%), 2 níveis de sacarose (1,5 e 3\%) e 3 freqüências de renovação dos meios (sem renovação, renovação aos 30 e aos 60 dias), com os meios acrescidos de ANA $(0,5 \mathrm{mg} / \mathrm{L})$ e BAP $(0,3 \mathrm{mg} / \mathrm{L}$.), semi-solidificados com ágar $0,7 \%$ e pH 5,7. Observou-se que a utilização do meio MS na concentração de sais completa, com a adição de 3\% de sacarose e renovações do meio em intervalos de 30 dias, apresentou melhor desenvolvimento dos eixos embrionários.
\end{abstract}

Termos para indexação: renovação, sacarose, ANA, BAP, concentração de sais.

\section{RESPONSE OF CUPUASSU EMBRYONIC AXES (Theobroma grandiflorum Schum.) TO SALTS CONCENTRATION, SUCROSE DOSES AND CULTURE MEDIUM RENEWAL}

\begin{abstract}
The effects of concentration of salts and sucrose and culture medium renewal frequency on cupuassu (Theobroma grandiflorum Schum.) embryonic axes development were studied. Two salts concentrations of MS (100 and 50\%), two sucrose levels (1.5 and 3\%) and three explants subcultives (without medium renewal, renewal at 30 and 60 days) were tested, with NAA $(0.5 \mathrm{mg} / \mathrm{L})$ and BAP $(0.3 \mathrm{mg} / \mathrm{L})$ in the MS medium. The use of MS at full concentration, with addition of $3 \%$ of sucrose, and renewals of the medium at 30 day intervals promoted better cupuassu embryonic axes development.
\end{abstract}

Index terms: renewal, sucrose, NAA, BAP, salts concentration.

O cupuaçuzeiro (Theobroma grandiflorum Schum.) é uma árvore frutífera, tipicamente amazônica, pertencente à família das Sterculiaceas, que se encontra disseminada por toda a bacia Amazônica, sendo esporadicamente encontrada em outros países, como a Colômbia, Venezuela, Equador e Costa Rica (Venturieri, 1993). Seus frutos fornecem uma polpa de cor amarelada, ácida, de sabor agradável, utilizada na fabricação de doces, sorvetes, licores, compotas, geléias, tortas, néctar enlatado, sucos, bombons e biscoitos (Calzavara, 1982; Venturieri, 1993). A gordura extraída das sementes é apropriada para a fabricação de cremes para a pele (Berbert, 1981), os quais são comercializados no Reino Unido (Venturieri, 1993).

Devido às sementes desta espécie serem recalcitrantes, mudas são formadas apenas na época de sua dispersão (Müller et al., 1995). Uma alternativa seria o emprego da cultura de tecidos, como técnica de propagação vegetativa, o que possibilitaria a produção de um maior número de mudas a partir de cada semente. Tentativas com a embriogênese somática possibilitaram apenas a obtenção de calos embriogênicos, que falharam na produção de "seedlings" viáveis (Velho et al., 1990). Contudo, as plantas cultivadas in vitro requerem uma fonte de energia exógena, pois não dispõem de condições adequadas para a realização da fotossíntese (Pierik, 1987; Grattapaglia \& Machado, 1990; Smith, 1992). A sacarose tem sido a fonte de carbono mais utilizada, devido à rapidez de sua absorção, estando presente em meios de cultura em concentrações que variam de 20 a $40 \mathrm{~g} / \mathrm{L}$.

Meios com potencial osmótico baixo são geralmente empregados para indução e crescimento de raízes em brotos micropropagados, enquanto altos níveis de sal geralmente retardam a iniciação radicular. Harris \& Stevenson (1982) testaram 4 concentrações de sais MS (1/4, 1/2, 3/4 e concentração completa) contra 4 níveis de sacarose $(1 ; 2 ; 3$ e $4 \%)$ e descobriram que a

1 (Trabalho 252/2000). Recebido: 17/11/2000. Aceito para publicação: 05/03/2002. Parte da tese de doutorado do primeiro autor apresentada à FCAV/ UNESP.

2 Eng. Agrôn., D.S., Pesquisadora da Embrapa Rondônia, Rod. BR-364, km. 5,5 Cx. Postal 406, Porto Velho, RO, CEP-78970-900. E-mail: mgraca@cpafro.embrapa.br.

3 Eng. Agrôn. M.S. Doutorando em Genética e Melhoramento de Plantas, ESALQ/USP, Av. Pádua Dias, CEP-13400-970, Piracicaba-SP.

4 Eng. Agrôn., Ph D., Pesquisador da Embrapa Milho e Sorgo, Cx. Postal 151, Sete Lagoas, MG, CEP-35701-970.

5 Biól., Ph. D., Pesquisadora da Embrapa Milho e Sorgo, Cx. Postal 151, Sete Lagoas, MG, CEP-35701-970.

6 Eng. Agrôn., D.S., Prof. Depto. de Biologia Aplicada à Agropecuária, FCAV-UNESP, Via de Acesso Prof. Paulo Donato Castellane, Km 05, Jaboticabal, SP, CEP-14870-000. 
TABELA 1 - Médias dos fatores principais para as variáveis massa fresca (MF), número de folhas por explante (NFE), área foliar (AF) e massa seca $(\mathrm{MS})^{1}$.

\begin{tabular}{|c|c|c|c|c|c|c|c|}
\hline \multirow[t]{2}{*}{ Variáveis } & \multicolumn{2}{|c|}{ Meios } & \multicolumn{2}{|c|}{ Níveis de sacarose } & \multicolumn{3}{|c|}{ Renovações } \\
\hline & $\mathrm{M}_{1}$ & $\mathrm{M}_{2}$ & $\mathrm{~S}_{1}$ & $\mathrm{~S}_{2}$ & $\mathrm{R}_{1}$ & $\mathrm{R}_{2}$ & $\mathrm{R}_{3}$ \\
\hline $\mathrm{MF}$ & $0,23 \mathrm{~A}$ & $0,24 \mathrm{~A}$ & $0,25 \mathrm{~A}$ & $0,23 \mathrm{~A}$ & $0,20 \mathrm{~B}$ & $0,24 \mathrm{~A}$ & $0,27 \mathrm{~A}$ \\
\hline NFE & $3,64 \mathrm{~A}$ & $3,50 \mathrm{~A}$ & $3,36 \mathrm{~A}$ & $3,88 \mathrm{~A}$ & $2,42 \mathrm{C}$ & $4,71 \mathrm{~A}$ & $3,58 \mathrm{~B}$ \\
\hline A F & $1,84 \mathrm{~A}$ & $0,99 \mathrm{~B}$ & $1,11 \mathrm{~B}$ & $1,72 \mathrm{~A}$ & $0,17 \mathrm{~B}$ & $3,6 \mathrm{~A}$ & $0,47 \mathrm{~B}$ \\
\hline M S & $0,06 \mathrm{~A}$ & $0,05 \mathrm{~B}$ & $0,05 \mathrm{~B}$ & $0,07 \mathrm{~A}$ & $0,04 \mathrm{C}$ & $0,08 \mathrm{~A}$ & $0,05 \mathrm{~B}$ \\
\hline
\end{tabular}

${ }^{1}$ Médias seguidas de letras iguais não diferem significativamente entre si pelo teste de Tukey a 5\% de probabilidade (P<0,05).

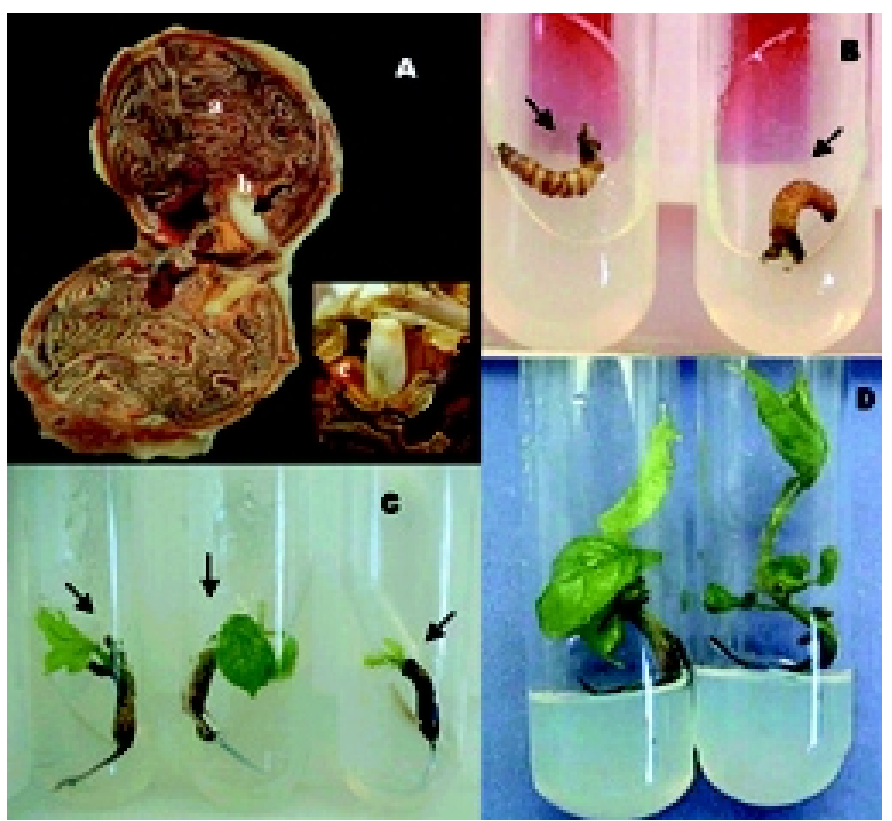

FIGURA 1 - A. Semente de cupuaçu: a. semente seccionada evidenciando os cotilédones; b. eixo embrionário; c. detalhe do eixo embrionário. B.C. Desenvolvimento de eixos embrionários no meio $M_{1}$. D. Plântulas de cupuaçu aos 150 dias.

concentração de sal (1/4 ou $1 / 2 \mathrm{MS})$ foi mais importante do que a concentração de sacarose para a indução radicular em estacas de videira in vitro.

Para manter a cultura, todo material ou parte deste deve ser transferido para meio fresco periodicamente, especialmente quando a densidade de células, tecido ou órgãos fica excessiva. O subcultivo aumenta o volume de uma cultura e/ou número de órgãos para micropropagação (George, 1993).

O objetivo deste trabalho foi estudar os efeitos da concentração de sais e sacarose e a freqüência de renovação do meio de cultura para o desenvolvimento de eixos embrionários de cupuaçu.

Foram utilizados como explantes, eixos embrionários obtidos de sementes de frutos de cupuaçu, adquiridos junto à Embrapa Amazônia Oriental, Belém-PA. As sementes foram esterilizadas pela imersão em álcool $70 \%$ durante três minutos, sob agitação. Foram feitas três lavagens com água destilada e, em seguida, as sementes foram imersas em solução de hipoclorito de sódio a $20 \%$ durante 20 minutos, sob agitação. Em câmara asséptica, foram lavadas 5 vezes com água bidestilada estéril e, com o auxílio de um bisturi, foram retirados os eixos embrionários dos cotilédones. Antes de serem transferidos para os meios de cultura, os eixos embrionários foram imersos em hipoclorito de sódio a $20 \%$ durante 10 minutos e, a seguir, foram feitas três lavagens com água bidestilada estéril.

O experimento foi conduzido no Laboratório de Cultura de Tecidos de Plantas, do Departamento de Biologia Aplicada à Agropecuária, pertencente à Faculdade de Ciências Agrárias e Veterinárias - UNESP/ Jaboticabal - SP. Utilizou-se um delineamento inteiramente casualizado, em arranjo fatorial $2 \times 2 \times$ 3 , sendo 2 concentrações de sais MS (Murashige \& Skoog, 1962) $\left(\mathrm{M}_{1}=100\right.$ e $\left.\mathrm{M}_{2}=50 \%\right), 2$ níveis de sacarose $\left(\mathrm{S}_{1}=1,5\right.$ e $\left.\mathrm{S}_{2}=3 \%\right)$ e 3 períodos de renovação dos meios $\left(\mathrm{R}_{1}=\right.$ sem renovação; $\mathrm{R}_{2}=$ renovação aos 30; e $\mathrm{R}_{3}=$ aos 60 dias), com seis repetições. Os meios foram acrescidos de ANA $(0,5 \mathrm{mg} / \mathrm{L})$ e BAP $(0,3 \mathrm{mg} / \mathrm{L}$.), semi-solidificados com ágar $0,7 \%$ e pH ajustado para 5,7 antes da autoclavagem. Os explantes foram colocados em tubos de ensaio e cultivados em sala de crescimento, com fotoperíodo de $8 / 16$ horas (escuro/claro) a $28^{\circ} \mathrm{C}$.

O experimento foi conduzido até os 150 dias após o explantio, ao final do qual foram feitas avaliações do crescimento das plântulas: massa fresca (g), massa seca (g), área foliar $\left(\mathrm{cm}^{2}\right)$ e número de folhas/explante. Para a determinação da área foliar, utilizou-se um digitalizador de imagem de resolução 9600 DPI acoplado a um microcomputador, no qual a imagem foi analisada com o programa PCXAREA.

$\mathrm{O}$ meio apresentou diferenças significativas entre seus níveis apenas para as variáveis área foliar (AF) e matéria seca (MS) (Tabela 1), o mesmo ocorrendo com a sacarose. A freqüência de renovação do meio apresentou diferenças significativas entre seus níveis para todas as variáveis analisadas.

$\mathrm{O}$ meio MS completo $\left(\mathrm{M}_{1}=100 \%\right)$ contribuiu para o desenvolvimento das plântulas. O número de folhas por explante (NFE), a área foliar (AF) e a matéria seca (MS) foram favorecidos quando se utilizaram 3\% de sacarose e renovações do meio de cultura a cada 30 dias. Resultados semelhantes foram relatados por Dunwell (1981), que observou aumento do peso seco quando a concentração de sacarose foi elevada.

$\mathrm{O}$ meio MS completo $\left(\mathrm{M}_{1}\right)$ apresentou as maiores médias, indicando que a espécie necessita de uma maior concentração de sais na fase de indução da parte aérea. Cheong et al. (1987) verificaram que a utilização do meio MS completo, suplementado com reguladores de crescimento, contribuiu para o desenvolvimento em altura e peso de plântulas de Ziziphus jujuba (Z. sativa).

Com exceção da massa fresca, a utilização de 3\% de 
sacarose $\left(\mathrm{S}_{2}\right)$ apresentou os melhores resultados, concordando com Searles et al. (1976), Pence et al. (1981), Wang \& Janick (1984), Kononowicz \& Janick (1984), Janick \& Whipkey (1985), Duhem \& Le Mercier (1989) e Söndhal et al. (1993) em trabalhos realizados com Theobroma cacao.

A renovação do meio foi fator fundamental no sucesso da propagação de plântulas de cupuaçu. Wang \& Janick (1984) também evidenciaram o efeito benéfico da renovação do meio na germinação precoce de embriões assexuais de cacau. George (1993) afirmou que a renovação do meio conduz à remoção de metabólitos tóxicos, fornecimento de nutrientes e hidratação, fatores que são prejudicados quando do crescimento do material vegetal em recipientes fechados.

Nas condições em que foram feitas este experimento, conclui-se que a concentração de sais, o nível de sacarose e a freqüência de renovação do meio de cultura, assim como suas interações, são fatores importantes no sucesso do desenvolvimento dos eixos embrionários de cupuaçu; a utilização da concentração de sais MS completa, $3 \%$ de sacarose e a renovação do meio aos 30 dias destacou-se como sendo a melhor condição para o desenvolvimento de eixos embrionários de cupuaçu, e pode ser recomendada para futuros estudos visando ao desenvolvimento de um protocolo comercial.

\section{REFERÊNCIAS BIBLIOGRÁFICAS}

BERBERT, P. R. F. Determinação do teor, ácidos graxos e características físicas das gorduras das sementes de Theobroma grandiflorum L. e do Theobroma bicolor L. e comparação com a gordura do Theobroma cacao L. Revista Theobroma, Ihéus, v.11,n.2, p. 91-98, 1981.

CALZAVARA, B.B.G. O cupuaçuzeiro (Theobroma grandiflorum Schum.). Belém. (s.n.) 1982. 11 p. (Série Cultivos Pioneiros).

CHEONG, S.T.; KIM, S. K.; PAEK, K.Y.; AHN, H.K. In vitro rooting and branching responses of jujube shoots as affected by growth regulators. Journal of the Korean Society for Horticultural Science, Suwon, v 28, n. 1, p. 53-60. 1987.

DUHEM, K.; LE MERCIER, N. Données nouvelles sur l'induction et le développement d'embryons somatiques chez Theobroma cacao L. Café Cacao Thé, Paris, v. 33, n. 1, p. 9-14, 1989.

DUNWELL, J. M. Influence of genotype and environment on growth of barley Hordeum vulgare embryos in vitro. Annals of Botany, London, n. 48, p. 535-542, 1981.

GEORGE, E. F. Plant tissue culture techniques. In: GEORGE, E. F. Plant propagation by tissue culture. Edington: Exegetics Limited, 1993, $574 \mathrm{p}$.

GRATTAPAGLIA, D.; MACHADO, M. A . Micropropagação. In: TORRES, A.C.; CALDAS, L.S., (Ed.) Técnicas e aplicações da cultura de tecidos de plantas. Brasília: ABCTP/EMBRAPACNPH, 1990.p. 99-169.

JANICK, J.; WHIPKEY, A. Axillary proliferation of shoots from cotyledonary nodal tissue of cacao. Revista Theobroma, Ilhéus, n. 15, p. $125-131,1985$.

HARRIS, R. E.; STEVENSON, J. H. In vitro propagation of vitis. Vitis, Siebeldingen, n. 21, p. 22-32, 1982.

KONONOWICZ, A. K; JANICK, J. In vitro development of zygotic embryos of Theobroma cacao. Journal of the American Society of Horticultural Science, Alexandria, v. 109, n. 2, p. 266269, 1984.

MÜLLER, C.H.; FIGUEIREDO, F.J.C.; NASCIMENTO, W.M.O. do.; GALVÃO, E.V.P.; STEIN, A.M.L.; NAZARÉ, R.F.R. de.; BARBOSA, W.C. A cultura do cupuaçu. Brasília: EMBRAPA SPI, 1995.61p.

MURASHIGE, T.; SKOOG, F. A revised medium for rapid growth and bio assays with tobacco tissue cultures. Physiologia Plantarum, Copenhagen, v. 15, p. 473-497, 1962.

PENCE, V. C.; HASEGAWA, P. M; JANICK, J. In vitro cotyledonary development and anthocyanin synthesis in zygotic and asexual embryos of Theobroma cacao. Physiologia Plantarum, Copenhagen, n. 53, p. 378-384, 1981.

PIERIK, R.L.M. In vitro culture of higher plants. Dordrecht: Martinus Nyhoff, 1987.344 p.

SEARLES, B. R.; ALVIM, P.T.; SHARP, W. R. Hormonal control of cellular proliferation in cultured callus derived from Theobroma cacao L. Revista Theobroma, Ilhéus, v. 6, n. 3, p. 77-81, 1976.

SMITH, R.H. Media components and preparation. In: SMITH, R.H. (Ed.) Plant tissue culture: techniques and experiments. San Diego: Academic Press, 1992. p.7-18.

SÖNDAHL, M. R.; LIU, S.; BELLATO, C.; BRAGIN, A. Cacao somatic embryogenesis. Acta Horticulturae, Wageningen, n. 336, p. 245-248, 1993.

VELHO, C.C.; WHIPKEY, A.; JANICK, J. Cupuassu: a new beverage crop for Brazil. In: INTERNATIONAL SYMPOSIUM NEW CROPS RESEARCH, DEVELOPMENT, ECONOMICS. 1990, Portland. Proceedings... 1990. p. 372-75.

VENTURIERI, G. A. Cupuaçu: a espécie, sua cultura, usos e processamento. Belém: Clube do Cupu, 1993. 108 p.

WANG, Y.; JANICK, J. Inducing precocious germination in asexual embryos of cacao. Hortscience, Alexandria, v. 19, n. 6, p. 839-841, 1984. 